\title{
Modified pork fat affects the lipoprotein metabolism of rats
}

\author{
J. Więcek ${ }^{1,4}$, J. Skomial ${ }^{2,3}$, B. Pastuszewska ${ }^{3}$ and E. Sawosz ${ }^{2}$ \\ Warsaw Agricultural University, \\ 'Department of Pig Breeding, \\ ${ }^{2}$ Department of Animal Nutrition and Feed Science \\ Ciszewskiego 8, 02-786 Warsaw, Poland, \\ 'The Kielanowski Institute of Animal Physiology and Nutrition, Polish Academy of Sciences \\ 05-110 Jablonna, Poland
}

\begin{abstract}
Two groups of 8 fatteners each were fed semi ad libitum from $22 \mathrm{~kg}$ till slaughter at $102 \mathrm{~kg}$, and two on a restricted level (-25\%) from 22 to $60 \mathrm{~kg}$ and semi ad libitum to $102 \mathrm{~kg}$. Within each feeding level, one group was given a diet supplemented with 0 and one with $4 \%$ linseed oil (LO), fed from 60 to $102 \mathrm{~kg}$. The backfat of pigs fed on diets with LO contained less SF $\Lambda$ and MUFA, and more PUFA, of both scries $n-6$ and n-3 fatty acids. Fat quality was then evaluated in an experiment on growing rats fed for 35 days on dicts containing $20 \%$ fat from pork of each group. Serum triglycerides and LDL cholesterol levels were lower in rats fed on pork fat from LO-supplemented groups. Restricted feeding of pigs slightly improved the fatty acid profile of backfat and, ultimately, the indices of lipid metabolism in rats.
\end{abstract}

KEY WORDS: lineseed oil, pork fat, rats, lipoproteins

\section{INTRODUCTION}

Consumption of pork and pork fat can significantly influence human health. Changes in the amount and proportions of fatty acids can modify the functional value of pork fat (Rosenvold and Andersen, 2003; Raes et al., 2004). Increases in polyunsaturated fatty acids, particularly of $n-3$, are beneficial for lipid metabolism in humans (Connor, 2000). The aim of the study was the evaluation of backfat quality from fatteners fed restricted or semi ad libitum amounts of mixtures supplemented or not with linseed oil.

\footnotetext{
${ }^{4}$ Corresponding author: e-mail: wiecek@delta.sggw.waw.pl
} 


\section{MATERIAL AND METHODS}

Backfat was obtained from fatteners of two groups fed semi ad libitum (A) during the whole period of fattening $(22-102 \mathrm{~kg}$ ) and two fed restricted $(-25 \%)$ amounts of feed $(\mathrm{R})$ in the growing period $(22-60 \mathrm{~kg})$ and semi ad libitum in the finishing period (60-102 kg). Within each feeding level, one group was fed a dict containing 0 ( $\mathrm{AC}$ and $\mathrm{RC}$ ) and the other $4 \%(\Lambda \mathrm{O}$ and $\mathrm{RO})$ linseed oil in the finishing period (Więcek and Skomiał, 2004). Evaluation of the backfat quality was conducted on growing Wistar rats fed diets (Table 1) containing $20 \%$ of backfat from all groups of pigs.

TABLE 1

Composition of diets for rats, $\%$

\begin{tabular}{lr}
\hline Item & \\
\hline Casein & 12.6 \\
DL-methionine & 0.2 \\
Sugar & 12.0 \\
Mineral mix AIN & 3.5 \\
Vitamin mix AIN & 1.0 \\
Chloride choline 50\% & 0.2 \\
Cellulose & 4.0 \\
Starch maize & 46.5 \\
Backfat & 20.0 \\
\hline
\end{tabular}

After 35 days the rats were killed and blood samples were taken from the abdominal vena cava. Serum lipid metabolism indices were analysed (Vitros DT 60 II system). The results were subjected to one-way analysis of variance, employing the Duncan test (SPSS, 2000).

\section{RESULTS}

The backfat from pigs fed diets with linseed oil ( $\mathrm{AO}$ and $\mathrm{RO}$ ) had the most beneficial fatty acid profile (Table 2). The fat from these groups contained the smallest amount (\%) of SFA and MUFA and the greatest of PUFA of both series n- 6 and $n-3$. The proportions of PUFA to SFA and PUFA n-6 to PUFA n- 3 were also improved by addition of linseed oil. The restricted feeding in the growing period caused a slight improvement in those indices in comparison with semi ad libitum feeding, however, the differences were not statistically significant.

Lower levels of triglycerides $(\mathrm{P} \leq 0.01)$, total cholesterol and LDL in comparison with $\mathrm{AC}$ and $\mathrm{RC}$, were found (Table 3 ) in the blood serum of rats (groups denoted with the same letters as the groups of fatteners) fed diets containing backfat from 
groups $\mathrm{AO}$ and $\mathrm{RO}$. At restricted feeding ( $\mathrm{ROr}$ and $\mathrm{RCr}$ ), higher levels of HDL and lower levels of other indices were noted than in rats fed diets containing backfat from fatteners fed semi ad libitum during the whole fattening period.

TABLE 2

Fatty acid profile (ISO 5508, 1990 and ISO 5509, 1978) of backfat, \%

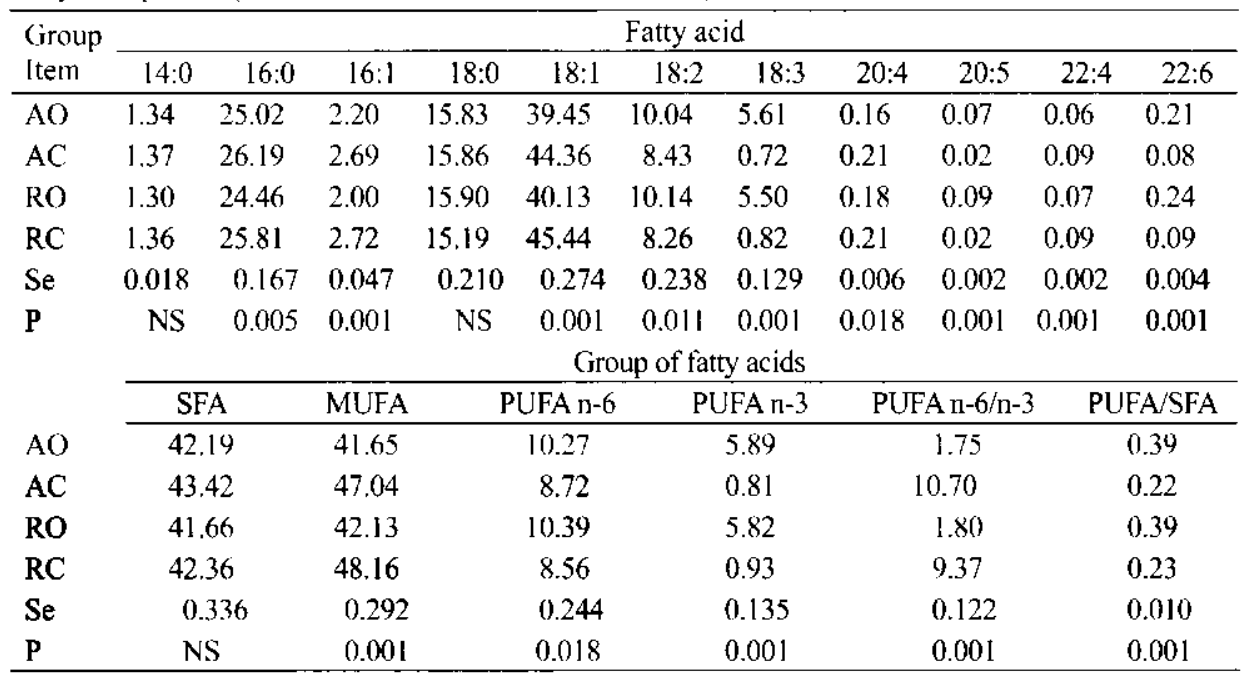

TABLE 3

Lipid metabolism indices in rats blood serum, $\mathrm{mg} / \mathrm{dl}$

\begin{tabular}{lccccc}
\hline \multirow{2}{*}{ Item } & \multicolumn{3}{c}{ Group } & \multirow{2}{*}{ Sc } \\
\cline { 2 - 5 } & \multicolumn{1}{c}{$\Lambda \mathrm{Or}$} & \multicolumn{1}{c}{$\Lambda \mathrm{Cr}$} & $\mathrm{ROr}$ & $\mathrm{RCr}$ & \\
\hline Triglycerides & $225.4^{\mathrm{A}}$ & $430.1^{\mathrm{B}}$ & $221.0^{\mathrm{A}}$ & 345.7 & 23.021 \\
Total cholesterol & 75.0 & 79.8 & 74.0 & 79.7 & 2.397 \\
HDL & 35.0 & 33.9 & 40.8 & 37.3 & 1.500 \\
LDL & 40.0 & $45.9^{\mathrm{A}}$ & $33.3^{\mathrm{Bb}}$ & $42.4^{\mathrm{a}}$ & 1.430 \\
\hline
\end{tabular}

means in rows followed by different superscripts differ significantly ${ }^{\mathrm{AB}}-\mathrm{P} \leq 0.01$; ${ }^{\text {ith }} \mathrm{P} \leq 0.05$

\section{DISCUSSION}

The positive changes in the fatty acid profile of backfat are a response of pigs to linseed oil added to their diets. A linear correlation between PUFA n-3 in the diet and in pork backfat was also found by Enser et al. (2000) and Raes et al. (2004). The rats responded to the diet containing various pork fats. Similarly to Chi et al. (1999), lower serum triglyceride and total cholesterol levels were found in rats fed on pig fat from linseed oil-supplemented groups. The response in rats shows that the fatty acid composition of pork fat, modified by linseed oil supplementation during 
the finishing period, can be enhanced by restricted feeding of pigs in the growing period of fattening. Only restricted feeding can slightly modify the fatty acid profile and influence the lipid metabolism in rats, but to a much smaller degree.

\section{CONCLUSIONS}

The linseed supplemented to pig diets markedly influenced the fatty acid profile of pork backfat and ultimately, the lipid metabolism in rats fed diets containing $20 \%$ of backfat. Restricted feeding enhanced this effect, but as a single experimental factor was weaker.

\section{REFERENCES}

Chi M.S., Ray R.L., Williams D.C., Vander Tuig M., (ralbreath K., 1999. Effects of dietary fat on blood pressure and plasma lipids in spontancously hypertensive rats. Nutr. Res. 19, 917-925

Connor W.E., 2000. Importance of n-3 fatty acids in health and disease. Amer. J. Clin. Nutr. 71, 171-175

Enser M., Richardson R.I., Wood J.D., Gill B.P., Sheard P.R., 2000. Feeding linseed to increase the n-3 PUFA of pork: fatty acid composition of muscle, adipose tissue, liver and sausages. Meat Sci. $55,201-212$

ISO, 5508, 1990. Animal and vegetable fats and oils - Analysis by gas chromatography of methyl esters of fatty acids

ISO, 5509, 1978. Animal and vegetable fats and oils - Preparation of methyl esters of fatty acids

Raes K., de Smet S., Demeyer D., 2004. Effect of dietary fatty acids on incorporation of long chain polyunsaturated fatty acids and conjugated linoleic acids in lamb, beef and pork meat: a review. Anim. Feed Sci. Tech. 113, 199-221

Rosenvold K., Andersen H.J., 2003. Factors of significance for pork quality: a review. Mcat Sci. 64 , 219-237

SPSS, 2000. 10.0 for Windows user's Guide, SPSS Ins. (USA)

Więcek J., Skomiał J., 2004. Restricted feeding and linseed oil as modifiers of the fatty acid profile in pork. J. Anim. Feed Sci. 13, Suppl. 2, 2004, 43-46

\section{STRESZCZENIE}

\section{Wplyw zmodyfikowanego tluszczu wieprzowego na przemiany lipoprotein u szczurów}

Dwie grupy tuczników po 8 sztuk każda, żywiono semi ad libitum przez caly okres tuczu (22-102 kg), a dwie ograniczonymi dawkami (-25\%) w pierwszym (22-60 kg) i semi ad libitum w drugim (60-102 kg) okresie tuczu. Przy każdym poziomie żywienia w drugim okresie tuczu jedna grupa otrzymywała dodatck 0 , a druga $4 \%$ olcju lnianego (LO). Słonina świń żywionych paszą 7. dodatkiem LO zawierała mniej SFA i MUFA, a więcej PLFA zarówno n-6 jak i n-3. W drugim doświadczeniu szczury rasy Wistar żywiono przcz 35 dni dietą zawicrającą $20 \%$ słoniny wieprzowej. Poziom trójglicerydów i cholesterolu fracji LDL w surowicy krwi szczurów otrzymujących w diecie słoninę o wyższej zawartości PUFA, szczcgólnic n-3 (dicty tuczników zawicrające 4\% LO) był niższy niż w pozostałych grupach. Ograniczone żywienie świń nieznacznie poprawiło profil kwasów tłuszczowych w stoninie i w konsekwencji wskaźniki przemian lipidowych u szczurów. 